\title{
EFEKTIFITAS PEMANFAATAN LAPORAN PAJAK ELEKTRONIK DI WILAYAH KANTOR PELAYANAN PAJAK (KPP) PRATAMA JAKARTA PELUIT - JAKARTA UTARA
}

\author{
BAHARUDDIN SAGA, WIZANASARI \\ Fakultas Ekonomi dan Bisnis, Universitas Pamulang \\ *Email: saga.baharuddin@yahoo.com
}

\begin{abstract}
This study presents the results of a qualitative study on the implementation of electronic tax reporting by taxpayers registered in KPP Pratama Jakarta Peluit, namely qualitative research with data collection methods using in-depth interviews with related parties such as taxpayers, also experts in the field being studied. Data collection is also carried out by means of a Group Discussion Forum (FGD) to determine the level of taxpayer compliance in electronic tax reporting, as well as finding the right solution to be able to use electronic tax reporting for taxpayers. All respondents in this study revealed that electronic tax reports are very helpful for taxpayers in the submission process of tax report, and are very efficient both in time and cost, but the ability of taxpayers to use electronics still needs guidance, even though all legal umbrellas have been made in such a way, especially for entrepreneurs. the "small" who incur high costs for this.
\end{abstract}

\section{Keywords: Effectiveness and Electronic Tax Report}

\begin{abstract}
ABSTRAK
Penelitian ini menyajikan hasil dari studi kualitatif tentang pelaksanaan pelaporan pajak elektronik oleh wajib pajak yang terdaftar pada KPP Pratama Jakarta Peluit yakni penelitian kualitatif dengan metode pengumpulan data dengan menggunakan wawancara yang mendalam dengan pihak yang terkait seperti wajib pajak yag terdaftar pada KPP Pratama Jakarta Peluit, juga para pakar pada bidang yang sedang di teliti. Selain itu pengumpulan data juga dilakukan dengan Focus group discussion (FGD) untuk mengetahui tingkat kepatuhan wajib pajak dalam pelaporan pajak elektronik, serta serta mencari solusi yang tepat untuk dapat menggunakan pelaporan pajak elektronik bagi wajib pajak. Semua responden dalam penelitian ini mengungkapkan bahwa laporan pajak elektronik sangat membantu wajib pajak dalam proses penyampaiannya, serta sangat efisien baik waktu maupun biaya, namun kemampuan wajib pajak dalam menggunakan elektronik masih perlu mendapatkan bimbingan, sekalipun semua payung hukumnya telah dibuat sedemikian rupa, terutama bagi pengusaha "kecil" yang terbebani biaya tinggi atas hal ini.
\end{abstract}

Kata Kunci: Effektifitas dan Laporan pajak elektronik 
Jurnal Ilmiah Akuntansi Universitas Pamulang - Vol. 9, No. 2 Juli 2021 - Saga \& Wizanasari

\section{PENDAHULUAN}

Sejak dikeluarkannya Peraturan Mentri Keuangan Republik Indonesia PMK NOMOR 243/PMK.03/2014, tgl 24 Desember 2014 tentang Surat Pemberitahuan (SPT), wajib pajak diberikan pilihan dalam penyampaian SPT (surat pemberitahuan) apakah bentuk hardcopy ataupun elektronik (softcopy), sedangkan untuk pembayaran pajak dilakukan dengan menggunakan e_billing di mana berdasarkan $e_{-}$billing dimaksud selanjutnya setelah pembayaran bank akan mengeluarkan NTPN sebagai bukti dan lampiran pelaporan pajak (STP) tersebut.

Pada awalnya penyampaian SPT dalam bentuk soft copy hanya berupa himbauan, namun sekarang penyampaian SPT dalam bentuk elektronik adalah sebuah keharusan seiring effisiensi yang dilakukan oleh direktur jedral pajak. Effisiensi ini sangat dirasakan dampaknya baik wajib pajak maupun direktur jedral pajak karena tidak harus berurusan lagi dengan tumpukan file-file bentuk hardcopy.

Pemanfaatan laporan pajak secara elektronik ini sudah dimulai sejak direktorat jendral pajak melakukan modernisasi pada tahun 2005 namun hingga saat itu hanya bersifat himbauan dan diberikan pilihan kepada wajib pajak untuk melakukan proses manual atau elektronik, di mana hal ini merupakan salahsatu bentuk pemakluman bagi wajib pajak, terkait masih banyaknya wajib pajak yang belum mampu menguasai komputer pelaporan pajak elektronik. Sejak diberlakukannya sistem pelaporan pajak dengan sistem elektronik, wajib pajak diwajibkan melaporkan pajakannya secara elektronik untuk mempermudah wajib pajak maupun DJP dalam mengakses dan memanfaatkan laporan pajak dimaksud.

Laporan pajak dengan sistem elektronik menjadi sangat penting karena pada dasarnya pajak adalah salah satu sumber penerimaan negara yang terbesar dibanding dengan sumber penerimaan dari sektor selain pajak, sehingga memerlukan sumberdaya pendukung yang kuat di satu sisi, sedangkan di sisi lain sistem administrasi pajak dan pelaporan pajak secara manual memiliki banyak kelemahan dan memakan waktu perekaman yang cukup lama serta tumpukan dokumen yang cukup besar dan memiliki standar pelaporan yang sama baik perusahaan kecil maupun perusahaan besar yang sangat merepotkan bagi direktorat jendral pajak. Karenanya DJP berusaha melakukan pembaharuan pada sistem dan layanan perpajakan dengan memodernisasi sistem administrasi perpajakan sehingga pelayanan menjadi lebih efektif dan efisien, (Andela \& Irawati, 2021)

Peraturan dan payung hukum yang baik diharapkan dapat mengawal pelaporan pajak dengan elektronik antara lain (e-SPT) sesuai dengan Per-DJP No: 19/PJ/2009 tentang Tata Cara Penerimaan dan Pengolahan SPT Elektronik yakni aplikasi yang digunakanan wajib pajak dalam bentuk elektronik, serta (eRegistration) yang diatur sesuai dengan Per-DJP No: PER-24/PJ/2009 tentang Tata Cara Pendaftaran NPWP dan Perubahan Data Wajib Pajak, Elektronik Registration, yaitu aplikasi berbasis online untuk mendaftarkan NPWP, pengukuhan PKP serta perubahan data wajib pajak.

Adapun bentuk laporan pajak manual yang telah dilakukan dengan bentuk laporan eketronik (E_SPT) adalah laporan bulanan dan laporan tahunan yakni SPT Masa dan SPT Tahunan serta proses pembayaranya (yakni SSP dan $e_{-}$billing). Dengan menggunakan sistem e-billing kinerja Wajip Pajak menjadi lebih berkualitas, lebih cepat selesai, (Irawati \& Priambodo, 2020).

* Corresponding author's e-mail: saga.baharuddin@yahoo.com

http://openjournal.unpam.ac.id/index.php/JIA 
Jurnal Ilmiah Akuntansi Universitas Pamulang - Vol. 9, No. 2 Juli 2021 - Saga \&

Wizanasari

Tabel 1 Proses Pelaporan Pajak

PROSES PELAPORAN PAJAK

\begin{tabular}{cll}
\hline No & Proses Manual (Periode Sebelum 2014) & \multicolumn{1}{c}{ Proses Elektronik (2014 - Sekarang) } \\
\hline 1 & Penyampaian Laporan Bulanan secara & $\begin{array}{l}\text { Penyampaian Laporan Bulanan secara } \\
\text { elektronik }\end{array}$ \\
2 & $\begin{array}{l}\text { Penyamal } \\
\text { manual }\end{array}$ & $\begin{array}{l}\text { Penyampaian Laporan Tahunan secara } \\
\text { elektronik }\end{array}$ \\
3 & Pembayaran dengan SSP & Pembayaran dengan $e$ billing \\
4 & Pembayaran dengan SSP Setor ke Bank & Pembayaran dengan $e$ billing Setor ke Bank \\
5 & Banyak document hardcopy & Dokumentasi elektronik dgn sedikit hardcopy \\
6 & Merepotkan WP dan DJP & Effisiensi pada WP dan DJP \\
7 & Pelaporan hanya pada jam kerja atau sesuai & Pelaporan dapat dilakukan selama 24 jam \\
& jadwal DJP & \\
\hline
\end{tabular}

Selain pelaporan secara elektronik ( $e$ filing) di atas, direktorat jendral pajak dalam mengawal penerimaan negara juga melakukan perubahan sistem administrasi perpajakan lainnya, melakukan perbaikan regulasi, dan edukasi perpajakan agar mencapai tujuan DJP sebagai institusi perpajakan yang kuat, kredibel dan akuntabel.

Dalam rangka mendorong sistem perpajakan Indonesia, maka perubahan sistem perpajakan dipayungi dengan peraturan pemerintah melalui KMK885/KMK.03/2016 menuju sistem perpajakan yang memenuhi rasa keadilan wajib pajak, serta perluasan database pajak yang valid, komprehensif, dan terintegrasi untuk meningkatkan penerimaan pajak yang berkesinambungan, bagi terwujudnya lembaga perpajakan yang kuat sesuai visi direktorat Jenderal Pajak yakni "Menjadi Institusi Penghimpun Penerimaan Negara yang Terbaik demi Menjamin Kedaulatan dan Kemandirian Negara", melalui SDM, anggaran, proses bisnis, sistem informasi, dan infrastruktur pendukung serta regulasi, yang mampu mendeteksi potensi pajak dan merealisasikannya menjadi penerimaan pajak

Untuk mewujudkan reformasi perpajakan ini, direktorat jendral pajak membentuk pilar optimasi penerimaan pajak sebagai berikut:

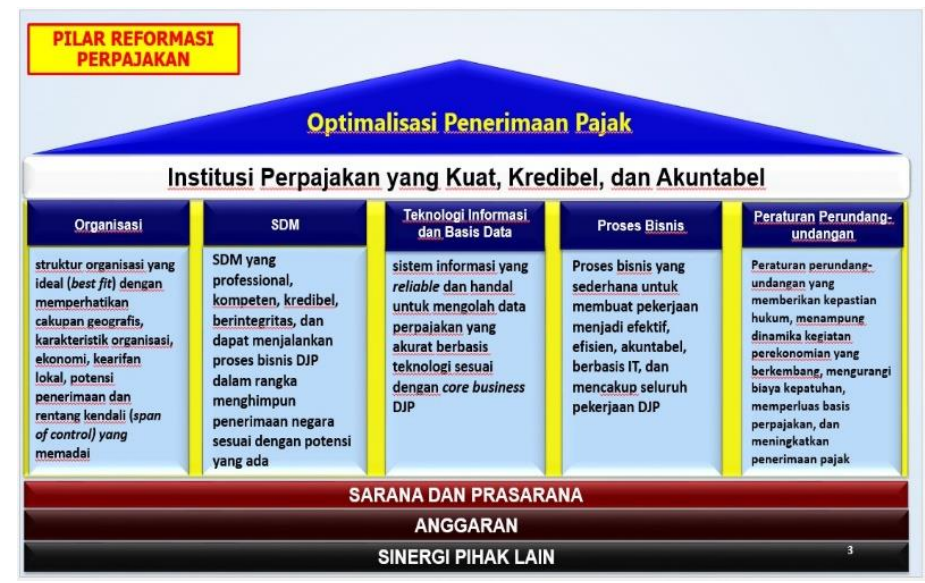

Sumber: www.pajak.go.id/reformasipeerpajakan

Gambar 1. Pilar optimasi penerimaan pajak

* Corresponding author's e-mail: saga.baharuddin@yahoo.com

http://openjournal.unpam.ac.id/index.php/JIA 
Wajib pajak masih perlu dikawal dan diikuti oleh petugas pajak dalam hal pemberian pemahaman dan/atau serta mengedukasi mereka agar melakukan kewajiban perpajaknya dengan baik seuai dengan amanat Undang-Undang Perpajakan. Edukasi kepada wajib pajak ini bukan hanya pada tatanan pemahaman terhadap peratutan perpajakan saja, namun juga terhadap teknis pelaksanaannya seiring perubahan metode dan pendekatan Direktorat Jendral Pajak dalam melakukan proses administrasi perpajakan sebagaimana diamanatkan oleh PERDJP No. PER- 02 /PJ/2019 yang dimuat dalam KUP pasal 1 poin 8, poin 9 dan poin 16 sebagaimana dimasud dalam peraturan ini, dengan memperhatikan peraturanpearturan pajak sebelumnya.

\section{LANDASAN TEORI}

\section{Efektivitas Penerimaan Pajak}

Menurut Kamus Besar Bahasa Indonesia (KBBI), efektivitas adalah dayaguna, keaktifan, serta adanya kesesuaian dalam suatu kegiatan antara seseorang yang melaksanakan tugas dengan tujuan yang ingin dicapai. Untuk mengetahui tingkat efektivitas menggunakan rumus sebagai berikut:

Efektivitas $=($ Output Aktual $/$ Output Target $) \geq 1$ atau

Sedangkan untuk mengukur efektifitas penerimaan pajak digunakan formula sebagai berikut:

Efektivitas Penerimaan Pajak $=$ Realisasi Penerimaan Pajak/Target Penerimaan Pajak x 100\%

Efektif adalah keaktifan, daya guna, adanya kesesuaian dalam suatu kegiatan orang yang melaksanakan tugas dengan sasaran yang dituju. Efektivitas menekankan pada hasil yang dicapai, sedangkan efisiensi lebih melihat pada proses pencapaian hasil dengan membandingkan antara input dan outputnya. efektivitas adalah pemanfaatan sumber daya, sarana dan prasarana dalam jumlah tertentu yang secara sadar ditetapkan sebelumnya untuk menghasilkan sejumlah barang atas jasa kegiatan yang dijalankannya. Efektivitas menunjukkan keberhasilan dari segi tercapai tidaknya sasaran yang telah ditetapkan. Jika hasil kegiatan semakin mendekati sasaran, berarti makin tinggi efektivitasnya. lain:

Aspek-aspek efektivitas berdasarkan pendapat Muasaroh (2010), antara

1) Aspek tugas atau fungsi, yaitu lembaga dikatakan efektivitas jika melaksanakan tugas atau fungsinya, begitu juga suatu program pembelajaran akan efektiv jika tugas dan fungsinya dapat dilaksanakan dengan baik dan peserta didik belajar dengan baik;

2) Aspek rencana atau program, yang dimaksud dengan rencana atau program di sini adalah rencana pembelajaran yang terprogram, jika seluruh rencana dapat dilaksanakan maka rencana atau program dikatakan efektif;

* Corresponding author's e-mail: saga.baharuddin@yahoo.com 
3) Aspek ketentuan dan peraturan, efektivitas suatu program juga dapat dilihat dari berfungsi atau tidaknya aturan yang telah dibuat dalam rangka menjaga berlangsungnya proses kegiatannya. Aspek ini mencakup aturan-aturan baik yang berhubungan dengan guru maupun yang berhubungan dengan peserta didik, jika aturan ini dilaksanakan dengan baik berarti ketentuan atau aturan telah berlaku secara efektif; dan

4) Aspek tujuan atau kondisi ideal, suatu program kegiatan dikatakan efektif dari sudut hasil jika tujuan atau kondisi ideal program tersebut dapat dicapai. Penilaian aspek ini dapat dilihat dari prestasi yang dicapai oleh peserta didik.

Pembelajaran atas peraturan tentang pajak elektronik ini telah dilakukan sosialisasi oleh DJP melalui sosialisasi, petunjuk-petunjuh dan himbauanhimbaiuan tentang teknis pelaksanaan peraturan dimaksud dan ditindak lanjuti oleh setiap kantor pelayanan pajak (KPP) diwilayah masing-masing untuk memacu dan mempermudah pengolahan data penerimaan pajak. Dalam menunjang program pelaporan pajak dengan metode eletronok $\left(e \_f i l l i n g\right)$ ini, secara teknis direktorat jendral pajak memberikan petunjuk dan kemudahan dalam pelaporan SPT ini, salah satu diantaranya adalah petunjuk teknis dan himbauan melalui pajak web pajak ituse diri yang dikenal dengan "klikpajak" dengan ikon "Bayar dan Lapor Pajak jadi Lebih Mudah di Klik Pajak dengan menampilkan beberapa kemudahan seperti Gratis Selamanya, Proses Cepat dan Mudah, support layanan, serta himbauan agar dilakukan 'Klik untuk daftar gratis"

Dapat dipastikan bahwa semua pelaporan SPT wajib pajak telah dilakukan melalui elektronik (e_filling). Proses ini adalah proses yang pasif (passive process) di mana sistem ini hanya dilakukan untuk mempercepat proses pelaporan dan mengurangi interaksi wajib pajak dengan kantor pelayan pajak secara langsung. Dilihat dari sisi pelaporan pajak dengan berbagai kelebihan dan kekurangannya, proses ini sangat membatu wajib pajak dan direktorat jendral pajak serta Kantor Pelayana Pajak diseluruh Indonesia. Namun dari sisi pengembangan dan peningkatan penerimaan negara dari sisi direktorat jendral pajak masih diperlukan pengembangan fungsi elektronik. sehingga memudahkan pemantauan dan tindak lanjut yang diperlukan. Melalui e-filing wajib pajak dapat melaporkan SPT Tahunan dengan praktis, mudah, cepat, dan efisien, (Avianto, et al., (2016).

Melalui SE-DJP Nomor: SE-06/PJ.9/2001 telah berupaya mengoptimasi penerimaan pajak dengan melakukan Ekstensifikasi Wajib Pajak terkait peningkatan jumlah wajib pajak dan objek pajak DJP serta Intensifikasi Pajak terkait optimasi penerimaan pajak terkait objek/subjek pajak yang telah tercatat pada administrasi DDJP, atas ekstensifikasi Wajib Pajak.

Selain itu dapat juga diketahui dari pihak ketiga, misalnya melalui adanya bukti pembayaran BPHTB/ PPHTB atas transaksi pembelian tanah dan atau bangunan, serta bukti potong PPh 23 dan Pajak final lainnya. Dalam hal penyitaan harta penunggak pajak untuk meningkatkan pendapatan negara, DJP masih mengandalkan informasi dari pihak ketiga, baik secara manual maupun secara elektronik. Dengan pemberian sanksi perpajakan, efektivitas penerimaan pajak menjadi lebih baik, (Irawati, et al., 2021).

Dalam persiapan payung hukum atas rencana DJP dalam mengakses rekening bank perorangan (misalnya) belum bisa dilakukan sehubungan dengan peraturan pemerintah (DPR/Dewan Perwakilan Rakyat dan BI/Bank Indonesia), di mana setiap usulan DJP melalui DPR yang diharapkan menjadi Kepres dan menjadi

* Corresponding author's e-mail: saga.baharuddin@yahoo.com 
Jurnal Ilmiah Akuntansi Universitas Pamulang - Vol. 9, No. 2 Juli 2021 - Saga \& Wizanasari

UU. Sejauh ini kerjasama antara bank dan direktorat jendral pajak masih sangat lemah sehingga direktorat jedral pajak memerlukan payung hokum untuk dapat mengakses data nasabah bank. Sejauh ini DJP terkesan bekerja sendiri untuk meningkatkan penerimaan negara tanpa dukungan yang optimal dari lembaga terkait, sementara di sisi lain oknum WP masih ada yang belum bisa menerima kehadiran petugas pajak.

Berbagai cara pemerintah telah dilakukan untuk meningkatkan ekonomi rakyat serta mendorong masyarakat untuk turut serta memberikan kemudahan dan simplifikasi model perpajakan UMKM, diantaranya penurunan tarif pajak atas UMKM yang sebelumnya diatur dengan PP. Nomor: 46 tahun 2013, yang mengatur dikenakannya PPh Final Pasal 4 Ayat (2) bagi wajib pajak yang memiliki omzet sampai dengan Rp. 4,8 miliar per-tahun pajak. Penurunan tarif pajak ini diatur dengan PP Nomor 23 tahun 2018 tentang $\mathrm{PPh}$ atas penghasilan dari usaha wajib pajak yang tertentu sebagai pengganti PP Nomor 46 tahun 2013, yang diberlakukan sejak 1 Juli 2018

\section{Penelitian Yang Relevan}

Tabel 2. Penelitian relevan

\begin{tabular}{|c|c|c|c|}
\hline No & Nama Peneliti & Penelitian & elitian \\
\hline 1. & 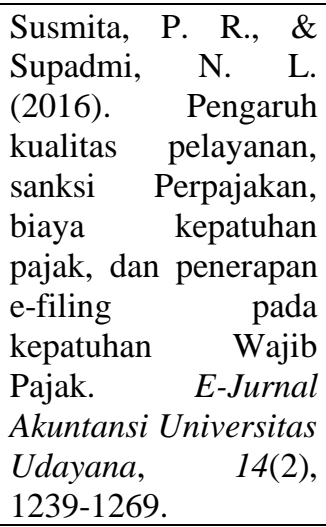 & $\begin{array}{lr}\text { Pengaruh } & \text { Kualitas } \\
\text { Pelayanan, } & \text { Sanksi } \\
\text { Perpajakan, } & \text { Biaya } \\
\text { Kepatuhan } & \text { Pajak, Dan } \\
\text { Penerapan } & \text { E-Filing } \\
\text { Pada Kepatuhan } & \text { Wajib } \\
\text { Pajak } & \end{array}$ & $\begin{array}{l}\text { Kualitas pelayanan berpengaruh } \\
\text { positif pada kepatuhan WP OP di } \\
\text { KPP Pratama Denpasar Timur. } \\
\text { Sanksi pajak berpengaruh positif } \\
\text { pada kepatuhan WP OP. } \\
\text { Pengenaan hukuman kepada WP- } \\
\text { OP yang melanggar peraturan } \\
\text { pajak berupa sanksi pajak. }\end{array}$ \\
\hline 2. & $\begin{array}{l}\text { Wulandari } \\
\text { Agustiningsih } \\
\text { Prodi Akuntansi } \\
\text { Universitas Negeri } \\
\text { Yogyakarta } \\
\text { Jurnal } \\
\text { Nominal/Volume V } \\
\text { No. 2 Tahun 2016 }\end{array}$ & $\begin{array}{l}\text { Pengaruh Penerapan E- } \\
\text { Filing, } \quad \text { Tingkat } \\
\text { Pemahaman Perpajakan } \\
\text { Dan Kesadaran Wajib } \\
\text { Pajak } \quad \text { Terhadap } \\
\text { Kepatuhan Wajib Pajak } \\
\text { Di Kpp Pratama } \\
\text { Yogyakarta }\end{array}$ & $\begin{array}{l}\text { Penerapan e-filing berpengaruh } \\
\text { positifdan signifikan terhadap } \\
\text { Kepatuhan WP di KPP Pratama } \\
\text { Yogyakarta. Tingkat pemahaman } \\
\text { perpajakan berpengaruh positif } \\
\text { dan signifikan terhadap Kepatuhan } \\
\text { WP di KPP Pratama Yogyakarta. }\end{array}$ \\
\hline 3. & $\begin{array}{l}\text { Lisa Tamara } \\
\text { Wibisono dan Agus } \\
\text { Arianto Toly } \\
\text { Program Akuntansi } \\
\text { Pajak Program Studi } \\
\text { Akuntansi Universitas } \\
\text { Kristen Petra } \\
\text { Tax Accounting } \\
\text { Review, Vol 4, No.1, } \\
2014\end{array}$ & $\begin{array}{lr}\text { Analisis } & \text { Faktor-Faktor } \\
\text { Yang } & \text { Mempengaruhi } \\
\text { Minat } & \text { Wajib Pajak } \\
\text { Dalam Penggunaan E- } \\
\text { Filing Di Sura }\end{array}$ & \begin{tabular}{lrr} 
Keamanan dan & \multicolumn{2}{r}{ kerahasiaan } \\
mempengaruhi minat WP dalam \\
menggunakan $\quad$ e-filing \\
Surabaya. Apabila tingkat \\
keamanan dan kerahasiaan \\
meningkat maka minat WP \\
menggunakan e-filing akan \\
meningkat pula.
\end{tabular} \\
\hline
\end{tabular}

* Corresponding author's e-mail: saga.baharuddin@yahoo.com

http://openjournal.unpam.ac.id/index.php/JIA 
Jurnal Ilmiah Akuntansi Universitas Pamulang - Vol. 9, No. 2 Juli 2021 - Saga \& Wizanasari

\begin{tabular}{|c|c|c|c|}
\hline 4. & $\begin{array}{l}\text { Ellyn Nurbaiti, Heru } \\
\text { Susilo Rosalita } \\
\text { Rachma Agusti PS } \\
\text { Perpajakan, Jurusan } \\
\text { Administrasi Bisnis, } \\
\text { Fakultas Ilmu } \\
\text { Administrasi, } \\
\text { Universitas } \\
\text { Brawijaya. } \\
\text { Jurnal Perpajakan } \\
\text { (JEJAK), Vol.9 No.1 } \\
\text { Tahu 2016 }\end{array}$ & $\begin{array}{l}\text { Pengaruh Implementasi } \\
\text { Sistem Elektronik Bagi } \\
\text { Wajib Pajak Terhadap } \\
\text { Kualitas Pelayanan } \\
\text { Administrasi Perpajakan }\end{array}$ & $\begin{array}{l}\text { hasil uji } F \text { tersebut diketahui } \\
\text { bahwa diperoleh nilai yang } \\
\text { signifikan dari ketiga variabel } \\
\text { bebas pada penelitian ini, hal ini } \\
\text { berarti variabel bebas berpengaruh } \\
\text { signifikan secara simultan } \\
\text { terhadap Kualitas Pelayanan } \\
\text { Administrasi Perpajakan. }\end{array}$ \\
\hline 5. & \begin{tabular}{lr}
\multicolumn{2}{l}{ Jullie J. Sondakh } \\
Fakultas & Ekonomi \\
dan & Bisnis, \\
Universitas & Sam \\
Ratulangi & Manado \\
Jurnal & InFestasi \\
Vol.13 & No.2 \\
Desember & 2017
\end{tabular} & $\begin{array}{lr}\text { Prediksi } & \text { Minat Perilaku } \\
\text { Menggunakan } & \text { Jasa } \\
\text { Pajak } & \text { Elektronik: } \\
\text { Analisis } & \text { Faktor } \\
\text { Konfirmatori } & \end{array}$ & $\begin{array}{l}\text { Hasil analisis masing-masing } \\
\text { indikator konstruk atau variabel } \\
\text { laten yang paling dominan dapat } \\
\text { dinyatakan bahwa apabila WP } \\
\text { mempunyai persepsi yang baik } \\
\text { atas kegunaan dan kemudahan } \\
\text { penerapan teknologi informasi } \\
\text { maka mereka akan menunjukkan } \\
\text { sikap yang positif untuk } \\
\text { memanfaatkan teknologi } \\
\text { informasi tersebut. }\end{array}$ \\
\hline 6. & 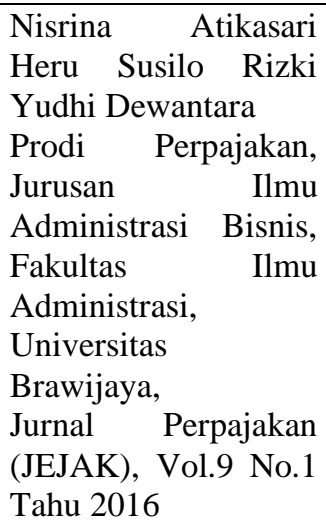 & $\begin{array}{lr}\text { Analisis } & \text { Penerapan } \\
\text { Faktur Pajak } & \text { Elektronik } \\
\text { Sebagai } & \text { Upaya } \\
\text { Mencegah Penerbitan } \\
\text { Faktur Pajak Fiktif } \\
\text { (Studi Pada Kantor } \\
\text { Pelayanan Pajak Pratama } \\
\text { Surabaya Gubeng) }\end{array}$ & $\begin{array}{l}\text { Memperkuat sistem teknologi } \\
\text { informasi, melakukan sosialisasi } \\
\text { secara maksimal dan terus- } \\
\text { menerus, melakukan controlling } \\
\text { serta penegakan hukum terkait } \\
\text { PKP yang melakukan kesalahan } \\
\text { pemenuhan kewajiban } \\
\text { perpajakannya dalam hal } \\
\text { penerapan FP Elektronik. }\end{array}$ \\
\hline 7. & $\begin{array}{l}\text { Danar Kiswara } \\
\text { I Ketut Jati } \\
\text { Fakultas Ekonomi } \\
\text { dan Bisnis } \\
\text { Universitas Udayana } \\
\text { ISSN:2302-8556, } \\
\text { E_Jurnal Akuntansi } \\
\text { Universitas Udayana } \\
\text { Vol.15.1 April 2016 }\end{array}$ & $\begin{array}{l}\text { Pengaruh Penerapan E- } \\
\text { Filing Dan Peran } \\
\text { Account Representative } \\
\text { Terhadap Pencitraan } \\
\text { Otoritas Pajak Dan } \\
\text { Kepatuhan Wajib Pajak }\end{array}$ & $\begin{array}{l}\text { Teknologi informasi dimanfaatkan } \\
\text { oleh otoritas pajak untuk } \\
\text { membentuk sistem e-Filing dalam } \\
\text { rangka modernisasi perpajakan } \\
\text { harus didukung oleh kenyamanan } \\
\text { dan keamanan untuk } \\
\text { meningkatkan pemenuhan } \\
\text { kebutuhan WP, agar tujuan } \\
\text { tersebut tercapai maka AR } \\
\text { berperan untuk memberikan } \\
\text { kenyamanan dan keamanan itu } \\
\text { dengan cara sosialisasi, } \\
\text { penyuluhan. Semakin sering WP } \\
\text { melakukan pelaporan pajak secara } \\
\text { benar dan efisien dengan sistem } e- \\
\text { Filing, semakin baik pencitraan } \\
\text { kepada otoritas pajak. }\end{array}$ \\
\hline 8. & $\begin{array}{l}\text { Nurul Citra Noviandri } \\
\text { FAKULTAS } \\
\text { EKONOMI } \\
\text { UNIVERSITAS }\end{array}$ & $\begin{array}{l}\text { Pengaruh Persepsi } \\
\text { Kebermanfaatan, } \\
\text { Persepsi Kemudahan } \\
\text { Penggunaan, Dan } \\
\text { Kepuasan Wajib Pajak }\end{array}$ & $\begin{array}{l}\text { Semakin tinggi tingkat } \\
\text { Kemudahan Penggunaan } e \text {-Filing, } \\
\text { WP akan semakin sering pula } \\
\text { menggunakan } e \text {-Filing. Kepuasan } \\
\text { pengguna mempengaruhi tingkat }\end{array}$ \\
\hline
\end{tabular}

* Corresponding author's e-mail: saga.baharuddin@yahoo.com

http://openjournal.unpam.ac.id/index.php/JIA 
Jurnal Ilmiah Akuntansi Universitas Pamulang - Vol. 9, No. 2 Juli 2021 - Saga \& Wizanasari

\begin{tabular}{|c|c|c|c|}
\hline & $\begin{array}{l}\text { NEGERI } \\
\text { YOGYAKARTA } \\
\text { Jurnal } \\
\text { Nasional/Volume } 1 \\
\text { Nomor 1/Tahun 2012 }\end{array}$ & $\begin{array}{l}\text { Terhadap Penggunaan E- } \\
\text { Filing Bagi Wajib Pajak } \\
\text { Di Yogyakarta }\end{array}$ & $\begin{array}{l}\text { penggunaan e- Filing. Semakin } \\
\text { tinggi tingkat Kepuasan } \\
\text { Pengguna, maka wajib pajak akan } \\
\text { semakin sering pula menggunakan } \\
\text { e-Filing. }\end{array}$ \\
\hline 9. & $\begin{array}{l}\text { Aulia Dyanrosi } \\
\text { Program Magister } \\
\text { Ilmu Administrasi } \\
\text { Bisnis, Universitas } \\
\text { Brawijaya } \\
\text { JISIP:Jurnal Ilmu } \\
\text { Sosial dan Ilmu olitik } \\
\text { ISSN 2442-6962 } \\
\text { Vol.4. No.2(2015) }\end{array}$ & $\begin{array}{l}\text { Analisis Perilaku Wajib } \\
\text { Pajak Orang Pribadi } \\
\text { Terhadap Minat Perilaku } \\
\text { Menggunakan E-Filing }\end{array}$ & $\begin{array}{l}\text { Pengalaman menggunakan e- } \\
\text { filing berpengaruh positif } \\
\text { signifikan terhadap minat untuk } \\
\text { menggunakan e-filing. Sikap } \\
\text { terhadap penggunaan e-filing } \\
\text { berpengaruh positif signifikan } \\
\text { terhadap minat perilaku untuk } \\
\text { menggunakan } e \text {-filing, WP } \\
\text { memberikan respon positif } \\
\text { terhadap penggunaan e-filing dan } \\
\text { akan melanjutkan untuk } \\
\text { menggunakannya di masa depan. }\end{array}$ \\
\hline
\end{tabular}

\section{Kerangka Berpikir}

Penelitian ini dibangun secara terstruktur yang sekaligus merupakan sebuah model/dan atau miniatur di mana akan menerangkan untuk apa penelitian ini dilakukan yang ditunjukan melalui proses dan tahapan serta langkah yang dilakukan yang diharapkan dapat diperoleh dalam penelitian ini.

Gambaran kerangka berpikir atas penelitan ini adalah sebagai berikut:

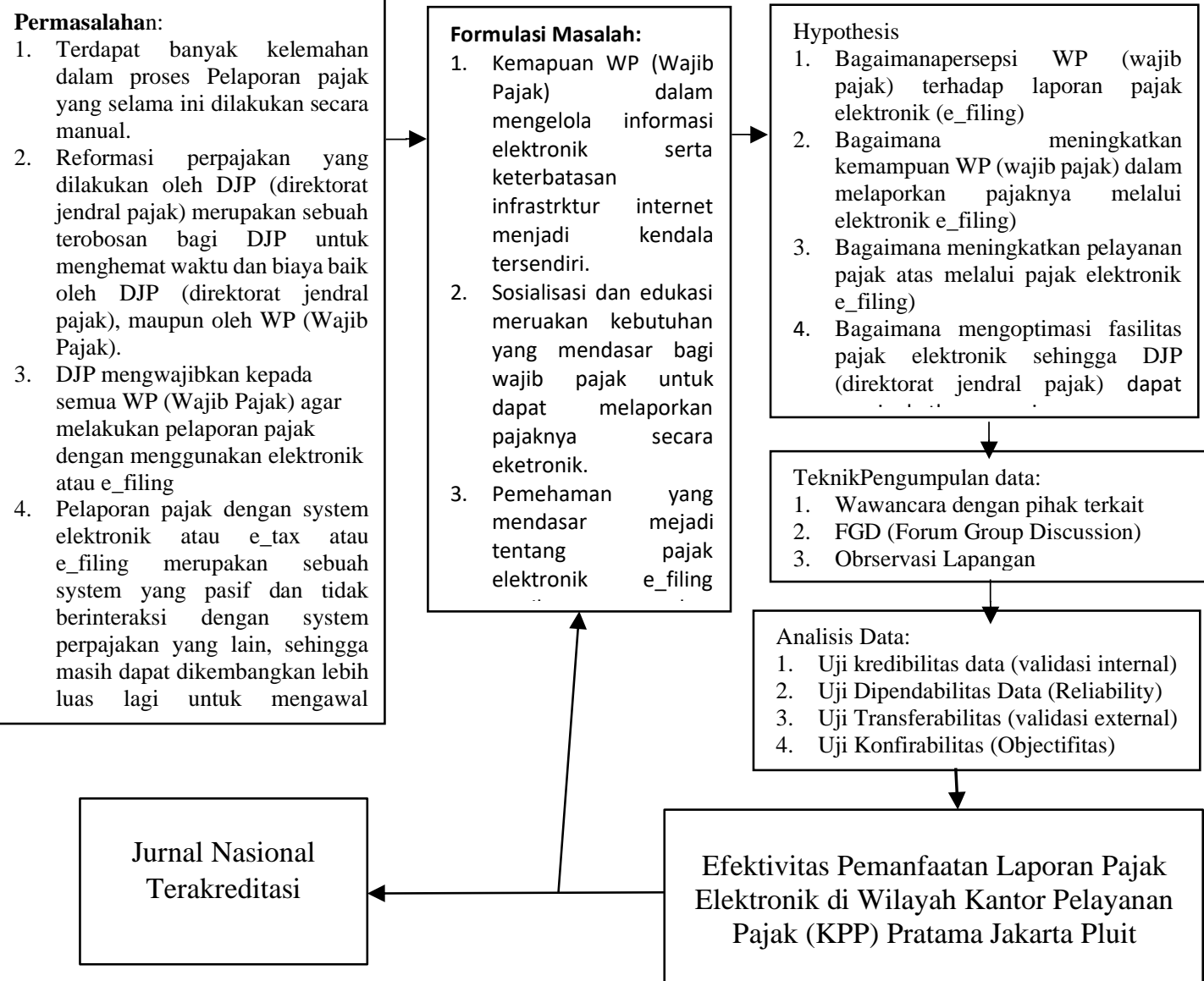

Gambar 3 Kerangka Berpikir

* Corresponding author's e-mail: saga.baharuddin@yahoo.com

http://openjournal.unpam.ac.id/index.php/JIA 
Jurnal Ilmiah Akuntansi Universitas Pamulang - Vol. 9, No. 2 Juli 2021 - Saga \& Wizanasari

\section{METODE PENELITIAN}

Penelitian kualitatif adalah metode penelitian yang didasarkan pada filsafat yang akan berhubungan langsung dengan data kualitatif, dan karenanya peneliti harus memberi makna atas fakta-fakta dilapangan, terutama dalam melakukan identifikasi dan lokasi sebagai fondasi awal yang akan dilakukan. Teknik pengumpulan data yang dilakukan secara gabungan analisis data bersifat induktif/kualitatif dan hasil penelitian kualitatif yang lebih menekankan pada makna generalisasi.

Penelitian ini akan dilakukan di Kantor KPP Pratama Jakarta Peluit, Alamat: Jalan Lodan No. 3 Ancol, Jakarta Utara, Telp: 021-6900771, 021-6900281, serta wajib pajak di lingkungan Kantor Pelayanan Pajak KPP Pratama Jakarta Peluit periode 2018, untuk mengindari terjadinya perluasan masalah yang tidak terkontrol. KPP Pratama Jakarta Pluit, memiliki Wajib Pajak pada tahun 2018 sejumlah 56.096 yang mengalami peningkatan dari tahun 2017 sebesar 2.142 Wajib Pajak atau sekitar 4\%, dengan jumlah penerimaan pajak ditahun 2018 sebesar Rp4.663.325.383.205 atau naik sebesar Rp1.439.950.812.394 atau sekitar 45\% dibanding tahun sebelumnya (2017)

Prosedur penelitian kualitatif dapat menghasilkan wawasan berdasarkan evaluasi dari WP dalam di lingkungan KPP Pratama Jakarta Peluit, dan persepsi terhadap laporan pajak SPT manual dan laporan pajak SPT berbasis elektronik.

Sample bertingkat digunakan untuk memastikan titik keseimbangan antara wajib pajak yang menyampaikan laporan pajak elektroniknya (e_spt) dan petugas kantor pelayanan pajak yang menerima laporan pajak elektroniknya (e_spt), di mana wajib pajak dibagi menjadi 3 group prioritas:

1. Wajib pajak yang melaporkan kewajiban perpajakaanya sendiri tanpa bantuan dari pihak manapun

2. Wajib pajak yang melaporkan kewajiban perpajakannya sendiri dengan bantuan dan arahan kantor pelayanan pajak.

3. Wajib pajak yang melaporkan kewajiban perpajakannya menggunakan konsultan pajak

Penelitian ini menggunakan metode wawancara semi struktur berdasarkan panduan wawancara yang telah ditentukan dan belangsung rata-rata 30 menit. Fokus wawancara adalah bagaimana persepsi wajib pajak terhad pelaporan pajak secara elektronik (e_spt). Melalui wawancara ini peneliti akan mendapatkan informasi tentang persepsi tersebut.

Wawancara dilakukan kepada

1. WP yang melaporkan pajaknya sendiri tanpa bantuan dari pihak manapun

2. WP yang melaporkan pajaknya sendiri dengan bantuan dan arahan KPP.

3. Wajib pajak yang melaporkan pajaknya menggunakan konsultan pajak

4. Ahli dibidang perpajakan

5. Pihak terkait seperti direktorat jendral pajak dan konsultan pajak

Observasi dilakukan langsung kepada wajib pajak yang secara elektronik untuk mengetahui dengan pasti penggunaan pelaporan pajak secarael ektronik (e_spt), terutama kepada wajib pajak yang melakukan pelaporan pajaknya sendiri tanpa bantuan dari fihak manapun. Observasi dilakukan terhadap beberapa wajib pajak sesuai sample yang telah ditetapkan yang berada di lingkungan KPP Pratama Jakarta Pluit.

* Corresponding author's e-mail: saga.baharuddin@yahoo.com

http://openjournal.unpam.ac.id/index.php/JIA 
Observasi harus disesuaikan dengan waktu wajib pajak, terutama mendekati jadwal jatuh tempo pelaporan pajak elektronik dan dilakukan langsung ke kantor wajib pajak, sehingga dapat dihasilkan pemahaman yang lebih optimal atas persepsi pelaporan pajak berbasis elektronik sesuai dengan kondisi riil.

\section{Wawancara Online Via Telepon Selular}

Hampir semua anggota masyarakat sudah memiliki telepon seluar sehingga untuk melengkapi informasi yang dibutuhkan dalam melengkapi penelitian ini dapat digunakan, demikian juga pertanyaan-pertanyaan tentang persepsi WP (wajib pajak) terhadap penggunaan pelaporan pajak berbasis elektronik, sehingga informasi yang didapatakan lebih lengkap dan diharapkan dengan wawancara online diharapkan lebih efektif dan efisien serta tidak mengganggu waktu responden.

\section{Teknik Analisa Data}

Data yang diperoleh dari hasil observasi, wawancara, catatan-catatan lapangan didokumentasikan secara terorganisir dan disusun secara sistematis yang dijabarkan, melakukan sintesa dan mengefaluasi berdasarkan tingkat kepentingan serta dibuat kesimpulan yang dengan mudah dapat dipahami oleh semua pihak

Analisa kualitatif bersifat induktif atas data yang diperoleh yang dikembangkan menjadi hipotesis. Berdasarkan hipotesis yang dirumuskan dan dikaji secara berulang yang selanjutnya disimpulkan apakah hipotesis tersebut diterima atau ditolak, di mana akan dikembangkan menjadi teori apabila hipotesis tersebut dikumpulkan secara berualang-ulang dengan tekhnik tranggulasi.

\section{HASIL DAN PEMBAHASAN}

\section{Karakteristik Responden Penelitian}

Penelitian qualitatif ini dilakukan untuk mengetahui efektifitas pemafaatan laporan pajak elektronik dengan objek penelitian WP-OP yang berada di lingkungan KanWil Jakarta Utara pada KPP Pratama Jakarta Peluit, dengan jumlah responden 30 wajib pajak dan telah memiliki NPWP lebih dari 5 tahun yang diharapkan dapat mewakili WPOP di lingkungan KPP Pratama Jakarta Peluit, karena pada dasarnya membahas konteks yang sama yang dilakukan oleh semua WPOP, baik dalam kapasitasnya sebagai karyawan dan WPOP dalam kapasitasnya sebagai pengusaha yang secara routine melakukan pajaknya dengan baik.

Penelitian ini juga dilakukan dengan berdiskusi langsung dengan narasumber dari diretorat jenderal pajak dan petugas pajak pada KPP Pratama Jakarta Peluit yang berhubungan langsung dengan para wajib pajak dan pada akhirnya ditutup degan FGD (focus group discussion) yang melibatkan narasumber dari diretorat jenderal pajak dan petugas pajak serta WP-OP dalam satu forum secara bersamasama. Adapun data WP-OP yang menjadi responden dalam penelitian ini adalah sebagai berikut:

* Corresponding author's e-mail: saga.baharuddin@yahoo.com 
Jurnal Ilmiah Akuntansi Universitas Pamulang - Vol. 9, No. 2 Juli 2021 - Saga \& Wizanasari

Tabel 3 Karateristik Responden Berdasarkan Jabatan WP

\begin{tabular}{rlr}
\hline No & Keterangan & Jumlah \\
\hline 1 & Karyawan & \multicolumn{2}{c}{14} \\
2 & Manager & \multicolumn{2}{c}{11} \\
$\mathbf{3}$ & Pengusaha & $\mathbf{5}$ \\
\hline Jumlah Wajib Pajak & $\mathbf{3 0}$
\end{tabular}

Tabel 4 Karateristik Responden Berkaitan Dengan Profesi/Pekerjaan WP

\begin{tabular}{rlr}
\hline No & Keterangan & Jumlah \\
\hline 1 & Enigineer & 16 \\
2 & Ekonomi/Keuangan & 10 \\
3 & Pengusaha & 4 \\
\hline Jumlah Wajib Pajak & $\mathbf{3 0}$ \\
\hline
\end{tabular}

\section{Focus group discussion (FGD)}

Pada dasarnya laporan pajak elektronik dimulai tahun 2011 yang awalnya e_SPT PPh tahunan orang pribadi dan berlanjut hingga hari ini hampir semua jenis pajak dilakukan dengan laporan elektronik/atau dilakukan secara online. Dari sisi direktorat jenderal pajak, laporan pajak elektronik memudahkan proses kerja direktorat jenderal pajak. Saat ini setiap laporan pajak elektronik sudah disampaikan, maka semua pengguna laporan pajak dalam lingkungan direktorat jenderal pajak langsung dapat mengakses laporan pajak dimaksud.

Keuntungan lain sesuai dengan keinginan kementrian keuangan yakni penghematan anggaran yang semula saat laporan pajak dilakukan secara manual, semua formuplir serta surat setoran pajak (SSP-sebanyak 5 rangkap) harus disipakan oleh direktorat jenderal pajak sehingga merupakan sebuah penghematan yang cukup besar bagi direktorat jenderal pajak, sekalipun saat ini belum semua wajib pajak menggunakan laporan pajak elektronik dalam melakukan kewajiban perpajakannya, namun secara bertahap pada akhirnya nanti semua wajib pajak harus menggunakan laporan pajak elektronik dalam melakukan kewajiban perpajakannya.

Adapun wajib pajak yang masih diperbolehkan menggunakan laporan pajak manual terutama wajib pajak orang pribadi, karena masih banyaknya keterbatasan kemajuan disetiap daerah serta keperduluan wajib pajak disetiap daerah. Bagi kotakota besar terutama di pulau di pulau Jawa pada dasarnya akan sangat sedikit wajib pajak yang resisten dengan laporan pajak elektronik karena infrastruktur pelaporannya seperti access internet sudah sangat mumpuni sehingga bisa dipaksakan, namun untuk dareah/kota-kota kecil yang masih bermasalah dengan sambungan internet, listrik dan sejenisnya akan sangat sulit untuk dipaksakan, terutama bila didaerah tersebut pengetahuan masyarakat tentang infrastruktur teknology yang masih sangat rendah akan menjadi masaalah tersendiri untuk dipaksakan untuk melakukan laporan pajak elektronik.

Tujuan lain diberlakukannya laporan pajak elektronik adalah untuk memudahkan dan menguntungkan bagi stakeholder DJP, adalah WP, yakni untuk memudahkan wajib pajak dalam proses pelaporan pajak, memudahkan dalam

* Corresponding author's e-mail: saga.baharuddin@yahoo.com

http://openjournal.unpam.ac.id/index.php/JIA 
mengarsibkan/mendokumentasinya, serta penghematan bagi wajib pajak serta mengurangi kesalahan dalam distribusi dokumen.

Adapun cara pelaporan pajak online dimaksud selain sejumlah peraturan ditetapkan pemerintahpun dalam hal ini direktorat jenderal pajak, juga menghimbau agar semua WP melakukan pajaknya secara online, yang terlebih dahulu harus memiliki EFIN yang dapat diperoleh melalui KPP di mana wajib pajak terdaftar.

\section{Wawancara}

Wawancara dilakukan dengan berbagai pihak terkait yang berkewajiban melakukan kewajiban perpajakannya dengan baik antara lain:

\section{Wajib Pajak yang melaporkan pajaknya sendiri}

Wawancara yang dilakukan kepada wajib pajak yang melaporkan pajaknya sendiri menyatakan bahwa menjalankan dan melaporkan kewajiban perpajakan secara elektronik sangat efektif dan menguntungkan dalam hal ini unit business (perusahaan) karena dari sisi laporan tidak perlu lagi menyampaikan hard copy secara langsung ke kantor pajak, sehingga tidak perlu lagi mengantri di loket dan tidak perlu lagi berdesak-desakan dalam antrian seperti pada masa-masa sebelumnya, dan mereka sangat menikmati model laporan pajak secara elektronik ini.

Adapun kendala yang dihadapi dalam laporan pajak elektronik adalah apabila wajib pajak melakukan pelaporan pajaknya di hari terakhir jatuh tempo sebuah laporan pajak, maka agak terkendala dengan aksess atau koneksi internet yang kemungkinan terjadi karena banyaknya wajib pajak yang melaporkan pajaknya pada hari-hari/menit-menit terakhir jatuhtempo sebual laporan pajak, namun kendala ini bukanlah kendala teknis pelaporan pajak itu sendiri dan dapat dengan mudah disiasati, yakni melakukan pembayaran dan pelaporan pajak elektronik sebelum jatuh tempo pembayaran/pelaporan.

Sekalipun terdapat kendala sebagaimana diungkap di atas, namun pada dasarnya laporan pajak elektronik sangat menguntungkan wajib pajak dan bahkan juga sangat menguntungkan bagi direktorat jenderal pajak. Adapun keuntungankeuntungan yang dapat dirasakan oleh wajib pajak adalah antara lain:

1.1. Penghematan dari sisi biaya/anggaran;

1.2. Semula semua wajib pajak harus mempersiapkan semua dokumen (hardcopy) baik laporan pajak dimaksud, maupun pembayaran (dengan SSP), dengan sejumlah copy/rangkap sesuai syarat yang telah ditentukan peraturan perundang-undangan perpajakan

1.3. Semula semua laporan harus disampaikan secara fisik ke kantor pajak/dan atau mengirimkan melalui kantor pos, sehingga diperlukan biaya pengiriman dan penyampaian fisik laporan pajak ke kantor pajak, namu sekarang hanya perlu mempersiapkan secara elektronik dan laporan pajak dapat disampaikan ke kantor pajak secara elektronik dan dapat dilakukan pengiriman di manapun kita berada/atau sambal mengerjakan pekerjaan lain

1.4. Semula wajib pajak harus menyimpan semua dokumen/file dalam jumlah besar yang memerlukan tempat baik Gudang maupun tempat file itu sendiri, seperti binder/ordner dengan risiko kebanjiran, kebakaran dan dimakan rayap serta beberapa risiko filing lainnya, dan dengan laporan

* Corresponding author's e-mail: saga.baharuddin@yahoo.com 
pajak elektronik, waib pajak hanya perlu menyimpan file dalam bentuk soft copy dan tidak memerlukan tempat yang luas serta minimum risiko yang harus ditanggung oleh wajib pajak.

2. Menghemat waktu, yakni tidak perlu datang secara fisik ke kantor pajak untuk menyampaikan laporan pajak namun cukup dengan mengirimkan lewat elektronik, dan selain itu wajib pajak tidak perlu membuang waktu menyusun dan menyimpan dokumen pajak serta minimum risiko yang harus ditanggung oleh wajib pajak atas dokumen pajak yang harus disimpan hingga beberapa periode.

\section{WP yang melaporkan pajaknya sendiri dengan bantuan dan arahan KPP.}

Wawancara yang dilakukan kepada wajib pajak yang melaporkan pajaknya sendiri dengan bantuan dan arahan KPP dalam hal ini AR Pajak menyatakan bahwa berdasarkan pengalamannya dalam menjalankan dan melaporkan kewajiban perpajakannya secara elektronik sangat efektif dan menguntungkan karena dari sisi laporan tidak perlu lagi menyampaikan hard copy ke kantor pajak dengan ukuran dan gramasi kertas telah ditentukan melalui peraturan perpajakan Indonesia di mana berpotensi ditolak oleh direktorat jenderal pajak atas ketidak sesuaian ukaran dan gramasi kertas dokument laporan pajak, serta tidak perlu lagi datang ke kantor pajak dan mengantri di loket, sehingga tidak perlu lagi berdesak-desakan dalam antrian seperti pada masa-masa sebelumnya.

\section{Wajib Pajak yang Melaporkan Pajaknya Menggunakan Konsultan Pajak}

Wajib pajak yang melaporkan pajaknya menggunakan konsultan pajak menyatakan bahwa berdasarkan pengalamannya dalam melaporkan kewajiban perpajakannya secara elektronik sangat efektif dan menguntungkan setiap wajib pajak baik itu wajib pajak pribadi karena dari sisi laporan tidak perlu lagi menyampaikan hard copy ke kantor pajak, tidak perlu lagi datang ke kantor pajak dan mengantri di loket, sehingga tidak perlu lagi berdesak-desakan dalam antrian seperti pada masa-masa sebelumnya. Selain itu wajib pajak sangat berhemat dari sisi biaya karena berkurnagnya waktu konsultan pajak dalam melakukan kewajiban perpajaannya selain keuntungan lain seperti penghematan dari sisi biaya/anggaran;

a. Wajib pajak harus mempersiapkan semua dokumen (hardcopy) baik laporan pajak dimaksud, maupun pembayaran (dengan SSP), dengan sejumlah copy/rangkap sesuai syarat yang telah ditentukan.

b. Wajib pajak harus menyimpan semua dokumen/file dalam jumlah besar yang memerlukan tempat baik gudang maupun tempat file itu sendiri, seperti binder/ordner dengan risiko kebanjiran, kebakaran dan dimakan rayap serta risiko lainnya, dengan laporan pajak elektronik, wajib pajak hanya perlu menyimpan file dalam bentuk soft copy dan tidak memerlukan tempat yang luas sehingga risiko yang harus ditanggung oleh wajib pajak bisa lebih diminimumkan.

Pada umumnya Wajib Pajak menggunakan jasa Konsultan Pajak dikarenakan minimnya pengetahuan mereka di bidang perpajakan, dengan menggunakan jasa Konsultan diharapkan kewajiban perpajakan dapat dilaksanakan dengan efektif dan efisien serta risiko yang minim, (Khairannisa \& Cheisviyanny, 2019).

* Corresponding author's e-mail: saga.baharuddin@yahoo.com 
Jurnal Ilmiah Akuntansi Universitas Pamulang - Vol. 9, No. 2 Juli 2021 - Saga \& Wizanasari

\section{Ahli dibidang perpajakan}

Wajib Pajak yang melaporkan pajaknya yang dibantu oleh orang yang ahli dalam bidang perpajakan menyatakan bahwa laporan pajak elektronik ini sangat menguntungkan semua pihak baik wajib pajak maupun otoritas pajak dan sangat menghemat waktu serta memiliki nilai tambah. Laporan pajak elektronik dapat dilakukan di manapun tanpa harus ke kantor pajak dan tidak perlu menyiapkan berbagai lampiran dokumen hard copy sebagai lampiran dari laporan pajak, serta tidak perlu gudang file dengan berbagai risiko, seperti kebanjiran, kebakaran, serta berbagai risiko lainnya.

\section{Pihak terkait seperti direktorat jendral pajak dan konsultan pajak}

Pihak terkait seperti direktorat jendral pajak dalam hal ini arahan AR Pajak dan konsultan pajak dan atau orang yang mempunyai keahlian dibidang perpajakan, menyatakan bahwa sebelum adanya laporan pajak elektronik merasa sangat terbebani dan prihatin melihat saat mengisi SPT pribadi dan teamnya yang setiap jatuh tempo pelaporan pajak bekerja extra dalam persiapan laporan dimaksud dengan sejumlah dokumen yang harus disampaikan ke kantor pajak bahkan mereka selalu lembur untuk memastikan bahwa laporan pajak yang akan disampaikan telah sesuai dengan peraturan dalam hal ketepatan angka dan verifikasi dokumen lampiran pajak dimaksud telah sesuai dengan peraturan perundang-undangan, namun setelah dilakukannya laporan pajak secara elektronik terlihat lebih simple sehingga karyawan yang menangani laporan pajak dapat mengembangkan diri dan melakukan pekerjaan lain yang lebih memiliki nilai tambah, serta dapat dilakukan di manapun dan juga tidak perlu menyiapkan berbagai lampiran dokumen hard copy sebagai lampiran, serta tidak perlu memiliki tempat khusus untuk gudang file atau Gudang dokumen dengan berbagai risiko.

\section{KESIMPULAN}

\section{Kesimpulan}

Dari hasil wawancara, FGD (focus group discussion) dan pembahasan sebelumnya dapat ditarik kesimpulan bahwa:

1) Wajib Pajak yang melaporkan pajaknya sendiri - Laporan pajak elektronik sangat membantu bagi setiap wajib pajak karena pelaporan pajak secara elektronik dapat dilakukan di manapun wajib pajak berada.

2) WP yang melaporkan pajaknya sendiri dengan bantuan dan arahan KPP laporan pajak elektronik memberikan kemudahan dan penghematan bagi wajib pajak baik penghematan waktu maupun penghematan biaya.

3) Wajib Pajak yang Melaporkan Pajaknya Menggunakan Konsultan Pajak Wajib pajak sangat diuntungkan dengan laporan pajak elektronik karena selain menghemat waktu juga menghemat biaya dalam hal pemanfaatan waktu konsultan pajak, sekalipun masih terkendala minimnya pengetahuan atas sistem pelaporan electronic terutama bagi karyawan/wajib pajak pada level supervisor kebawah yang telah memenuhi persyaratan formal menjadi wajib pajak yang tidak memiliki pengetahuan tentang perpajakan.

* Corresponding author's e-mail: saga.baharuddin@yahoo.com 
Jurnal Ilmiah Akuntansi Universitas Pamulang - Vol. 9, No. 2 Juli 2021 - Saga \& Wizanasari

\section{4) Ahli dibidang perpajakan}

Laporan pajak elektronik ini sangat menguntungkan semua pihak baik dan memiliki nilai tambah, namun diperlukan sosialisasi, pleatihan dan pembelajaran baik langsung di kantor pelayanan pajak, maupun kantor-kantor di mana wajib pajak bekerja.

5) Pihak terkait seperti direktorat jendral pajak dan konsultan pajak

Pihak terkait seperti direktorat jendral pajak dalam hal ini arahan AR Pajak dan konsultan pajak dan atau orang yang mempunyai keahlian dibidang perpajakan, sebelum adanya laporan pajak elektronik sangat terbebani saat mengisi SPT pribadi dan bekerja extra dalam persiapan laporan pajak dengan sejumlah dokumen yang harus disampaikan dan verifikasi sesuai dengan peraturan perundang-undangan.

\section{Saran - Saran}

1) Metode pelaksanaan sosialisasi oleh direktorat jenderal pajak perlu dievaluasi kembali dan ditingkatkan karena terindikasi bahwa setiapkali dilakukan sosialisasi/pelatihan pajak atas setiap peraturan perpajakan, hanya dihadiri oleh wajib pajak yang itu-itu juga atau wajib pajak yang sama.

2) Direktorat Jenderal Pajak perlu berkolaborasi dengan perusahaan-perusahaan dan atau institusi-institusi dalam memberikan pelatihan pajak kepada karyawan dan wajib pajak pribadi lainnya agar wajib karyawan dapat melakukan pelaporan pajak elektroniknya secara mandiri

3) Direktorat jenderal pajak perlu menunjuk duta-duta pajak yang diambil dari wajib pajak pribadi/dan badan dalam mamacu kepatuhan wajib pajak sebagai wujud tanggungjawab bersama wajib pajak dan direktorat jenderal pajak.

4) Direktorat jenderal pajak perlu meningkatkan fungsi laporan pajak elektronik secara terintegrasi, dan terus melakukan sosialisasi kepada seluruh wajib pajak dalam melakukan pajakanya dengan teliti.

\section{DAFTAR PUSTAKA}

Andela, A. P., \& Irawati, W. (2021). Pengaruh Persepsi Kegunaan, Keamanan dan Kerahasiaan Serta Kesiapan Teknologi Informasi terhadap Intensitas Penggunaan E-Filing. EkoPreneur, 2(1), 1-15.

Agustiningsih W. Pengaruh Penerapan E-Filing, Tingkat Pemahaman Perpajakan Dan Kesadaran Wajib Pajak Terhadap Kepatuhan Wajib Pajak Di Kpp Pratama Yogyakarta. Nominal Vol 5 (2) : 1007-122

Atikasari N, Susilo H, Dewantara Ry. 2016. Analisis Penerapan Faktur Pajak Elektronik Sebagai Upaya Mencegah Penerbitan Faktur Pajak Fiktif. Jurnal Perpajakan Vol 9 (1): 1-8

Avianto, G. D., Rahayu, S. M., \& Kaniskha, B. (2016). Analisa Peranan E-Filing Dalam Rangka Meningkatkan Kepatuhan Pelaporan Surat Pemberitahuan Tahunan Wajib Pajak Orang Pribadi (Studi Pada Kantor Pelayanan Pajak Pratama Malang Selatan). Jurnal Mahasiswa Perpajakan, 9(1).

* Corresponding author's e-mail: saga.baharuddin@yahoo.com 
Jurnal Ilmiah Akuntansi Universitas Pamulang - Vol. 9, No. 2 Juli 2021 - Saga \& Wizanasari

Dyanrosi, Aulia. 2015. Analisis Perilaku Wajib Pajak Orang Pribadi Terhadap Minat Perilaku Menggunakan E-Filing. Jurnal Ilmu Sosial Dan Ilmu Politik Vol 4 (2) : 361-373

Irawati, W., \& Priambodo, B. (2020). Pengaruh Faktor Sosial dan Ekspektasi Kinerja terhadap Tax Billing System. Jurnal Kajian Akuntansi, 4(2), 156169.

Irawati, W., Mustaqim, M., \& Barli, H. (2021). Application of Modern Tax Administration System on The Effectiveness of Tax Reception with Tax Sanctions as Moderating Variables. Point of View Research Accounting and Auditing, 2(2), 122-128.

Khairannisa, D., \& Cheisviyanny, C. (2019). Analisis Peranan Konsultan Pajak Terhadap Kepatuhan Wajib Pajak Dalam Memenuhi Kewajiban Perpajakan. Jurnal Eksplorasi Akuntansi, 1(3), 1151-1167.

Kiswara D, Jati Ik. 2016. Pengaruh Penerapan E - Filing Dan Peran Account Representative Terhadap Pencitraan Otoritas Pajak Dan Kepatuhan Wajib Pajak. Jurna Forum Ilmiah Pendidikan Akuntansi Vol 5(1) : 249-377

Komite Pelaksana Sertifikasi Konsultan Pajak - Susunan Dalam Satu Naskah Uu No. 20 Thn 2000, Uu No.14 Thn 2002, Uu No.16 Thn 2016

Muasaroh, L. (2010). Aspek-Aspek Efektivitas. Yogyakarta: Literatur Buku.

Noviandri Cn. 2012. Pengaruh Persepsi Kebermanfaatan, Persepsi Kemudahan

Penggunaan, Dan Kepuasan Wajib Pajak Terhadap Penggunaan E-Filing Bagi Wajib Pajak. Jurnal Nasional Vol. 1 (1):15-23

Nurbaiti E, Susilo H, Agusti Rr. 2016. Pengaruh Implementasi Sistem Elektronik Bagi Wajib Pajak Terhadap Kualitas Pelayan Anadministrasi Perpajakan. Jurnal Perpajakan Vol 9 (1) : 1-9

PMK Nomor: 243/Pmk.03/2014, Tanggal 24 Desember 2014 Tentangsurat Pemberitahuan (Spt)

PER- DJP Ri Nomor: Per - 02/Pj/2017, Tanggal 13 February 2017 Tentang Perubahan Atas Peraturan Djp Nomor Per - 27/Pj/2016 Tentang Standar Pelayanan Ditempat Pelayanan Terpadu Kantor Pelayanan Pajak

Pmk Per - 02/Pj/2019, Tanggal 23 January 2019 Tata Cara Penyampaian, Penerimaan Dan Pengolahan Surat Pemberitahuan (Spt)

Se Djp Nomor:Se - 84/Pj/2011, Tanggal 15 November 2015 Tentang Pelayanan Prima

Sondakh Jj. 2017. Prediksi Minat Perilaku Menggunakan Jasa Pajak Elektronik: Analisis Factor Konfirmatori. Jurnal Infestasi Vol 1 Pengaruh Kualitas Pelayanan, Sanksi Perpajakan, Biaya Kepatuhan Pajak, Dan Penerapan EFiling Pada Kepatuhan Wajib Pajak. Jurnal Akuntansi Universitas Udayana Vol 14(2) : 1239-1269

Susmita Rp, Supadmi Ln. Pengaruh Kualitas Pelayanan, Sanksi Perajakan, Biaya Kepatuhan Pajak, Dan Penerapan E-Filling Pada Kepatuhan Wajib Pajak. E-Jurnal Akuntansi Universitas Udayana Vol 14(2) : 1239-1269

Wibisono Tl, Toly Aa. 2014. Analisis Factor-Faktor Yang Mempengaruhi Minat Wajib Pajak Dalam Penggunaan E-Filing Di Sura. Tax And Accounting Review Vol 4 (1):1-15

* Corresponding author's e-mail: saga.baharuddin@yahoo.com 